\title{
CORPORAL COMPOSITION OF SWINE FEED FROM 10 TO 20 KG WITH DIETS CONTAINING DIFFERENT LEVELS OF LYSINE AND CRUDE PROTEIN
}

\author{
Composição corporal de suínos alimentados dos 10 aos $20 \mathrm{~kg}$ com rações contendo diferentes \\ níveis de lisina e proteína bruta
}

\author{
Márcio Gilberto Zangeronimo ${ }^{1}$, Elias Tadeu Fialho ${ }^{2}$, Luis David Solis Murgas ${ }^{1}$, Raimundo Vicente de Sousa ${ }^{1}$, \\ José Augusto de Freitas Lima², Níkolas de Oliveira Amaral ${ }^{3}$
}

\begin{abstract}
The aim of this work was to verify the effect of different levels of true digestible lysine (TDL) and crude protein (CP) on diets on the carcass composition of the swine in the nursery phase. Eighty piglets Landrace $\mathrm{x}$ Large White, barrows and females, with initial weight of $9.1 \pm 1.2 \mathrm{~kg}$ and final weight of $21.5 \pm 4.8 \mathrm{~kg}$, weaned at the 28 days, allotted in groups of two during 35 days in the nursery. A randomized block design in factorial $2 \times 4$ (two levels of CP - 16 and $18 \%$ - and four of TDL - 0.7; 0.9; 1.1 and $1.3 \%$ ) with five repetitions was used. After weighing, one animal of each stall was sacrificed and the carcass utilized for determination of water (CWP), protein (CPP) and lipid (CLP) percentage and deposition tax of the protein (DTP) and lipid (DTL). There were no differences for CWP, but there was had quadratic effect of the lysine levels on the CPP and DTP in the carcasses only in $18 \%$ CP diets, being $1.02 \%$ of TDL that propitiated the best result for DTP. There was no difference in $16 \%$ CP diets. For the CLP, there were no differences when $18 \% \mathrm{CP}$ diets were utilized, however there was had quadratic effect with $16 \% \mathrm{CP}$ diets, being $0.99 \%$ the level of TDL that provided the higher deposition. For the DTL, the 1.08 and $1.00 \%$ of TDL resulting in higher values in 18 and $16 \%$ CP diets, respectively. One concluded that $18 \% \mathrm{CP}$ diets is the ideal and the $1.02 \%$ of TDL must be kept for the best carcass composition of swine in the initial phase.
\end{abstract}

Index terms: Synthetic amino acids, carcass composition, nutrition, piglets.

\section{RESUMO}

Objetivou-se verificar o efeito dos níveis de lisina digestível verdadeira (LDV) e proteína bruta (PB) nas rações sobre a composição de carcaça de suínos na fase inicial. Foram utilizados 80 suínos Landrace x Large White, machos castrados e fêmeas, com peso inicial de $9,1 \pm 1,2 \mathrm{~kg}$ e final de $21,5 \pm 4,8 \mathrm{~kg}$, desmamados aos 28 dias, alojados em grupos de dois, durante 35 dias na creche. Foi utilizado um delineamento em blocos casualizados em esquema fatorial $2 \times 4$ (dois níveis de PB - 16 e 18\% e quatro de LDV - 0,7; 0,9; 1,1 e 1,3\%) com cinco repetições. Após a pesagem, um animal de cada baia foi abatido e as carcaças utilizadas para determinação da porcentagem de água $(\% \mathrm{~A})$, proteína $(\% \mathrm{P})$ e lipídios $(\% \mathrm{~L})$ e taxa de deposição de proteína (TDP) e lipídios (TDL). Não houve diferenças para \%A na carcaça. Houve efeito quadrático dos níveis de lisina na \%P e TDP na carcaça apenas em rações com $18 \%$ PB, sendo 1,02\% de LDV o nível que proporcionou melhor resultado. Não houve diferença em rações com 16\% PB. Para \%L, não houve diferença quando $18 \%$ PB foi utilizado, porém houve efeito quadrático com $16 \%$ PB, sendo $0,99 \%$ o nível de LDV que proporcionou a maior deposição. Para TDL, os níveis de 1,08 e 1,00\% de LDV resultaram em maiores valores em rações com 18 e $16 \%$ PB, respectivamente. Conclui-se que $18 \%$ PB na ração é o ideal e que 1,02\% de LDV deve ser mantido para uma melhor composição de carcaça de suínos na fase inicial.

Termos para indexação: Aminoácido sintético, composição da carcaça, nutrição, leitões.

(Received in january 24, 2008 and approved in september 11, 2008)

\section{INTRODUCTION}

Aiming to satisfy the demand of consumer market, the genetic profit business had worried in produce new lineage, objectifying the increase of meat production in detriment of fat one. Thus, the application of modern concepts in the diet formulation, among them, the ideal protein concept has been abundantly raised, since is linked at best dietetic nitrogen utilization (KERR et al., 2003) and, consequently, at lesser elimination of this element in the excrements (FIGUEROA et al., 2002), without to affect the animal performance (LE BELLEGO et al., 2002).

Moreover, the reduction of crude protein in the diet supplied with crystalline amino acids has been associated at higher fat tissue accumulation due to lesser caloric increment propitiated by these diets and, consequently, higher quantity of energy deposited in fat

\footnotetext{
1 Veterinary Medicine Department, Federal Lavras University, Lavras, Minas Gerais, Brazil, zip code 37200-000 - zangeronimo@dmv.ufla.br

2 Animal Science Department - UFLA

${ }^{3}$ Master in monogastric nutrition - UFLA
} 
form (LE BELLEGO et al. 2001). Furthermore, the amino acid unbalance also has been associated at this factor, since the excess of these nutrients is degraded and the energy deriving from carbon skeleton is utilized for lipid synthesis in the organism (VERSTEGEN \& DE GREEF, 1992).

Some works have showed that the nutrient manipulations in diet can influence the performance (AROUCA et al., 2007; ZANGERONIMO et al., 2009), nitrogen metabolism (OLIVEIRA et al., 2005; ZANGERONIMO et al., 2007a), physiologic parameters (ZANGERONIMO et al., 2007b) and carcass composition (OLIVEIRA et al., 2006). Other ones (SUSENBETH, 1995; TRINDADE NETO et al., 2004) observed differences in the protein deposition tax in detriment of lipid in pigs in nursery phase manipulating only the lysine levels in the diet. Meanwhile, these effects were observed in high crude protein level diet. Agreement these authors, the excess of amino acids propitiated by high crude protein is changed in lipid, mainly when the lysine is the main limiting amino acid. Thus, it can have an ideal ratio between lysine and other amino acids to propitiate the maximum protein synthesis in the animals' carcass in decreasing the lesser fat deposition.

The possibility of reduction of crude protein, applying the ideal protein concept, supposes the necessity of best definition of the amino acid requirements. The objective of this work was to verify if the lysine levels, maintaining its ratio with methionine and threonine can influence the weight and the corporal composition of pigs in nursery phase receiving diets with different crude protein levels.

\section{MATERIALAND METHODS}

The experiment was carried out in the Experimental Farm of the Animal Science Department of Lavras Federal University (UFLA). Eight barrows and female, crossbred (Landrace $\mathrm{x}$ Large White), weaned at 28 days old, with initial weight of $9.1 \pm 1.2 \mathrm{~kg}$ and final weight of $21.5 \pm 4.8$ $\mathrm{kg}$. Beginning, three animals were slaughter for measurement of the initial chemistry composition of the carcasses.

The experimental diets followed the suggestion of Rostagno et al. (2000) with corn, soybean meal, gluten meal $60 \%$ and modified powder milk, being two levels of crude protein (16 and 18\%) and four levels of true digestible lysine $(0.7 ; 0.9 ; 1.1$ and $1.3 \%)$, completing eight treatments correcting the methionine and threonine levels following the ideal protein concept. The composition of experimental diets is showed in table 1 .

The animals were distributed in twice group in nursery building with temperature partially controlled with lamps and fan, in suspended box at $1.2 \mathrm{~m}(2.0 \times 1.2 \mathrm{~m})$ with latticework floor and semi-automatic feeders and pacifier type drinkers, during 35 days. At the final period, consume in each experimental unit was determined to estimate the metabolizable energy and digestible lysine intake. Following, the average weight gain (in grams) of each experimental unit was divided by lysine intake (in grams) to determine the efficiency of lysine utilization to weight gain.

In each experimental unit, an animal with weight next at the share average was slaughtered after insensibility to determine the carcass chemistry composition. After the evisceration, the total carcass was middle sawed in the median line and the half carcass containing the tail was weighted and froze, being then ground in $5.0 \mathrm{~mm}$ screen and uniformed, whose sample was removed to laboratorial analysis. The humidity, the ethereal extract and the crude protein were determined in Animal Nutrition Laboratory of Federal Lavras University, according to methodology described by Silva \& Queiroz (2002).

The statistics analysis were made in randomized blocks design in factorial scheme 2 x 4 (two levels of crude protein and four levels of true digestible lysine) with five repetitions, being the blocks represented by initial weight of the animals.

The slaughter weight $(\mathrm{kg})$, the daily metabolizable energy intake (kcal/day) and lysine intake (g/day), the efficiency of lysine utilization for gain $(\mathrm{g} / \mathrm{g})$, the humidity, protein and lipid in the carcass and the fat and protein deposition tax were evaluated. Data were submitted at the analysis of variance and the regression analysis for lysine levels when it has significance. The computer program Sisvar (FERREIRA, 2000) was utilized for analysis.

\section{RESULTS AND DISCUSSION}

The results obtained for daily lysine intake, metabolizable energy intake and efficiency of lysine utilization are showed in table 2. 
Corporal composition of swine feed...

Table 1 - Composition and amino acid ratio of experimental diets.

\begin{tabular}{|c|c|c|c|c|c|c|c|c|}
\hline \multirow{3}{*}{ Ingredient } & \multicolumn{8}{|c|}{ Experimental Diet } \\
\hline & \multicolumn{4}{|c|}{$18 \% \mathrm{CP}$} & \multicolumn{4}{|c|}{$16 \% \mathrm{CP}$} \\
\hline & $0.7 \%$ lys & $0.9 \%$ lys & $1.1 \%$ lys & $1.3 \%$ lys & $0.7 \%$ lys & $0.9 \%$ lys & $1.1 \%$ lys & $1.3 \%$ lys \\
\hline Corn & 59.00 & 59.00 & 59.00 & 59.00 & 59.00 & 59.00 & 59.00 & 59.00 \\
\hline Soybean meal & 20.00 & 20.00 & 20.00 & 20.00 & 15.60 & 15.6 & 15.60 & 15.60 \\
\hline Gluten meal 60 & 4.20 & 4.20 & 4.20 & 4.20 & 4.20 & 4.20 & 4.20 & 4.20 \\
\hline Soybean oil & 1.90 & 1.90 & 1.90 & 1.90 & 1.90 & 1.90 & 1.90 & 1.90 \\
\hline Modified milk powder & 5.00 & 5.00 & 5.00 & 5.00 & 5.00 & 5.00 & 5.00 & 5.00 \\
\hline Starch cassava & 4.60 & 4.60 & 4.60 & 4.60 & 8.60 & 8.60 & 8.60 & 8.60 \\
\hline Dicalcium phosphate & 1.63 & 1.63 & 1.63 & 1.63 & 1.68 & 1.68 & 1.68 & 1.68 \\
\hline Limestone & 0.80 & 0.80 & 0.80 & 0.80 & 0.80 & 0.80 & 0.80 & 0.80 \\
\hline Salt & 0.30 & 0.30 & 0.30 & 0.30 & 0.30 & 0.30 & 0.30 & 0.30 \\
\hline Vitamin $\operatorname{mix}^{1}$ & 0.10 & 0.10 & 0.10 & 0.10 & 0.10 & 0.10 & 0.10 & 0.10 \\
\hline Mineral $\operatorname{mix}^{2}$ & 0.10 & 0.10 & 0.10 & 0.10 & 0.10 & 0.10 & 0.10 & 0.10 \\
\hline L-lysine $\mathrm{HCl}(78 \%)$ & 0.00 & 0.28 & 0.56 & 0.85 & 0.15 & 0.43 & 0.72 & 1.00 \\
\hline DL-methionine $98 \%$ & 0.00 & 0.00 & 0.05 & 0.12 & 0.00 & 0.02 & 0.08 & 0.14 \\
\hline L-threonine & 0.00 & 0.011 & 0.14 & 0.28 & 0.00 & 0.08 & 0.21 & 0.34 \\
\hline Antibiotic & 0.03 & 0.03 & 0.03 & 0.03 & 0.03 & 0.03 & 0.03 & 0.03 \\
\hline $\begin{array}{l}\text { Butylated } \\
\text { hydroxytoluene }\end{array}$ & 0.01 & 0.01 & 0.01 & 0.01 & 0.01 & 0.01 & 0.01 & 0.01 \\
\hline Kaolim & 2.30 & 1.90 & 1.30 & 0.70 & 2.30 & 1.80 & 1.20 & 0.50 \\
\hline Sodium bicarbonate & 0.00 & 0.13 & 0.26 & 0.39 & 0.25 & 0.38 & 0.52 & 0.65 \\
\hline Total & 100 & 100 & 100 & 100 & 100 & 100 & 100 & 100 \\
\hline \multicolumn{9}{|c|}{ Calculed Values } \\
\hline $\mathrm{DE}(\mathrm{kcal} / \mathrm{kg})$ & 3401 & 3401 & 3401 & 3401 & 3414 & 3414 & 3414 & 3414 \\
\hline $\mathrm{ME}(\mathrm{kcal} / \mathrm{kg})$ & 3154 & 3154 & 3154 & 3154 & 3172 & 3172 & 3172 & 3172 \\
\hline Crude protein $(\%)$ & 18.00 & 18.00 & 18.00 & 18.00 & 16.00 & 16.00 & 16.00 & 16.00 \\
\hline Calcium & 0.83 & 0.83 & 0.83 & 0.83 & 0.82 & 0.82 & 0.82 & 0.82 \\
\hline Available phosphorus (\%) & 0.43 & 0.43 & 0.43 & 0.43 & 0.42 & 0.42 & 0.42 & 0.42 \\
\hline Digestible lysine (\%) & 0.70 & 0.90 & 1.10 & 1.30 & 0.70 & 0.90 & 1.10 & 1.30 \\
\hline Digestible threonine (\%) & 0.59 & 0.59 & 0.73 & 0.86 & 0.52 & 0.59 & 0.73 & 0.86 \\
\hline Digestible tryptophan (\%) & 0.16 & 0.16 & 0.16 & 0.16 & 0.14 & 0.14 & 0.14 & 0.14 \\
\hline Digestible methionine $(\%)$ & 0.29 & 0.289 & 0.34 & 0.40 & 0.26 & 0.28 & 0.34 & 0.40 \\
\hline \multicolumn{9}{|c|}{ Amino Acid Ratio } \\
\hline Lysine & 100 & 100 & 100 & 100 & 100 & 100 & 100 & 100 \\
\hline Threonine & 83 & 66 & 66 & 66 & 74 & 66 & 66 & 66 \\
\hline Tryptophan & 23 & 18 & 15 & 13 & 20 & 15 & 13 & 11 \\
\hline Methionine & 41 & 32 & 31 & 31 & 37 & 31 & 31 & 31 \\
\hline $\mathrm{M}+\mathrm{C}$ & 80 & 63 & 51 & 43 & 73 & 57 & 47 & 40 \\
\hline Arginine & 137 & 107 & 88 & 74 & 118 & 92 & 75 & 64 \\
\hline Isoleucine & 93 & 73 & 60 & 51 & 83 & 64 & 53 & 44 \\
\hline Valine & 103 & 81 & 66 & 56 & 92 & 72 & 59 & 50 \\
\hline Leucine & 241 & 189 & 155 & 131 & 224 & 174 & 142 & 121 \\
\hline Histidine & 61 & 48 & 39 & 33 & 55 & 43 & 35 & 29 \\
\hline Fenilalanine & 116 & 91 & 74 & 63 & 104 & 81 & 66 & 56 \\
\hline Fen. + Tyr. & 196 & 154 & 126 & 107 & 177 & 137 & 112 & 95 \\
\hline
\end{tabular}

LYS - true digestible lysine; DE - digestible energy; ME - metabolizable energy

${ }^{1}$ Vitamin supplement containing by kg of product: Vitamin A, 8,000,000 UI; vitamin $\mathrm{D}_{3}$, 1,200,000 UI; vitamin E, 20,000 mg; vitamin $\mathrm{K}_{3}, 2,500 \mathrm{mg}$; vitamin $\mathrm{B}_{1}, 1,000 \mathrm{mg}$; riboflavin $\left(\mathrm{B}_{2}\right), 4,000 \mathrm{mg}$; pyridoxine $\left(\mathrm{B}_{6}\right), 2,000 \mathrm{mg}$; vitamin $\mathrm{B}_{12}, 20,000 \mathrm{mcg}$; niacin, 25,000 mg; pantothenic acid, 10,000 mg; folic acid, $600 \mathrm{mg}$; biotin, $50 \mathrm{mg}$; vitamin C, 50,000 mg; antioxidant, $125 \mathrm{mg}$.

${ }^{2}$ Mineral supplement containing by kg of product: Selenium, $500 \mathrm{mg}$; Iron, $70.000 \mathrm{mg}$; Cupper, $20.000 \mathrm{mg}$; Manganese, 40.000 mg; Zinc, 80.000 mg; Iodine, 800 mg; Cobalt, 500 mg. 
Table 2 - Daily lysine intake and metabolizable energy intake and efficiency of lysine utilization for pigs from 10 to 20 $\mathrm{kg}$ receiving diets with different crude protein and digestible lysine levels.

\begin{tabular}{|c|c|c|c|c|c|}
\hline \multicolumn{6}{|c|}{ Metabolizable Energy Intake (kcal/day) } \\
\hline \multirow{2}{*}{ Crude protein $(\%)$} & \multicolumn{4}{|c|}{ Lysine level $(\%)$} & \multirow{2}{*}{ Average } \\
\hline & 0.7 & 0.9 & 1.1 & 1.3 & \\
\hline 16 & 2370 & 2445 & 2180 & 2055 & 2262 \\
\hline 18 & 2234 & 2372 & 2304 & 2390 & 2325 \\
\hline Average & 2302 & 2408 & 2242 & 2223 & \\
\hline $\mathrm{CV}(\%)$ & 12.02 & & & & \\
\hline \multicolumn{6}{|c|}{ Daily Lysine Intake (g/day) } \\
\hline \multirow{2}{*}{ Crude Protein (\%) } & \multicolumn{4}{|c|}{ Lysine level (\%) } & \multirow{2}{*}{ Average } \\
\hline & 0.7 & 0.9 & 1.1 & 1.3 & \\
\hline 16 & 5.23 & 6.94 & 7.56 & 8.42 & 7.04 \\
\hline 18 & 4.96 & 6.77 & 8.03 & 9.85 & 7.40 \\
\hline Average $^{1}$ & 5.09 & 6.85 & 7.80 & 9.14 & \\
\hline $\mathrm{CV}(\%)$ & 11.84 & & & & \\
\hline \multicolumn{6}{|c|}{ Efficiency of Lysine Utilization (weight gain $(\mathrm{g}) / \mathrm{g}$ lysine intaked) } \\
\hline \multirow{2}{*}{ Crude Protein (\%) } & \multicolumn{4}{|c|}{ Lysine level (\%) } & \multirow{2}{*}{ Average } \\
\hline & 0.7 & 0.9 & 1.1 & 1.3 & \\
\hline 16 & 66.7 & 54.1 & 49.5 & 41.2 & 52.9 \\
\hline 18 & 68.4 & 62.7 & 54.2 & 40.1 & 56.4 \\
\hline Average $^{1}$ & 67.6 & 58.4 & 51.8 & 40.7 & \\
\hline $\mathrm{CV}(\%)$ & 11.20 & & & & \\
\hline
\end{tabular}

${ }^{1}$ Significant linear effect $(\mathrm{P}<0.01)$

There was no difference $(\mathrm{P}>0.05)$ between the treatments for metabolizable energy intake. How expected, there was linear increase $(\mathrm{P}<0.05)$ of lysine intake while as the concentration of this amino acid increase in the diet, independent of crude protein level. With regard to efficiency of lysine utilization, there was no effect $(\mathrm{P}>0.05)$ of CP x lysine interaction, but there was linear effect $(\mathrm{P}<0.05)$ in this variable while as the lysine level increase in the diet, independent of crude protein level tested (figure 1).

This result can be explained by reduction of crude protein in the diet, whose amino acid available in di and tripeptides also can have been reduced. Associated this, the addiction of some amino acids of excessive form can generate an unbalance in the sites of protein synthesis in the cell, because the higher speed of absorption of this amino acids in the gastrointestinal tract (BAKER, 1996). In accordance to Zaloga (1990), just $33 \%$ of protein is absorbed wherein amino acid and, the remainder $(67 \%)$, wherein small peptides. Thus, the reduction of crude protein in the diet and the supplementation with amino acids (in this case the lysine, methionine and threonine) can limit the use of others nutrients, inducing the lesser efficiency of lysine utilization.

The values obtained to carcass chemistry composition are showed in table 3 . There were no difference
$(\mathrm{P}>0.05)$ in the slaughter animal weight, how expected. There were also no difference $(\mathrm{P}>0.05)$ with regard to humidity in the carcass, but there are effect of interaction between lysine and crude protein diet for protein and lipid percentage $(\mathrm{P}<0.01)$. the lysine levels did not influence $(\mathrm{P}>0.05)$ the carcass protein percentage of the animals that received $16 \%$ crude protein diet; nevertheless these levels showed quadratic effect $(\mathrm{P}<0.01)$ in the group that received $18 \%$ crude protein diet, whose true digestible lysine level that resulted in higher percentage was $1.01 \%$ (figure 2).

These results oppose at ones found by Oliveira (2004), whose work showed that the animals that received unbalance diets in amino acids showed lower humidity in the carcass. According to Kyriazakis et al. (1994), the differences obtained in the carcass lipid and carcass protein percentage explain the difference in the carcass humidity induced by treatments. Agreement Trindade Neto et al. (2004), the increase of water quantity is linked at the higher protein synthesis and this at the higher increase weight pitch. During the growth, the protein synthesis is destined to muscle development in direct ratio with the water increase. In the carcass, water corresponds at $75 \%$ of lean tissue and, in fat, only $25 \%$ (FULLER \& WANG, 1990). 


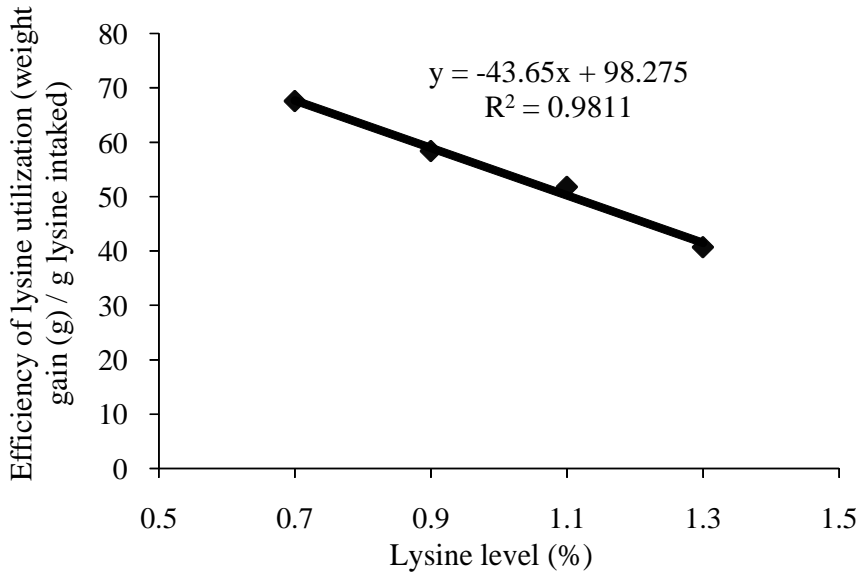

Figure 1 - Efficiency of lysine utilization for piglets from 10 to $20 \mathrm{~kg}$ receiving diets with 16 and $18 \%$ of crude protein and crescent levels of true digestible lysine.

Actually, studies conducted by Kerr et al. (2003) verified influence of the crude protein in diet on the corporal water concentration. By other hand, the differences observed by Fontes et al. (2005) in protein and far deposition taxes and in fat percentage in female pig from 15 to $30 \mathrm{~kg}$ did not interfere in the carcass humidity percentage, results alike at these evidenced by Tuitoek et al. (1997).

In the present work there were no difference in the carcass humidity, whose must be linked at protein synthesis once this tissue show higher water quantity in regard to fat tissue. In this experiment, by the fact the animals slaughtered be young, wherein the protein deposition tax is plenty accentuate in detriment of fat deposition tax can had been decisive factors in the obtainment of these results of humidity. Moreover, the effects raised by unbalanced amino acids can not have been sufficient to caused significant differences in the carcass humidity percentage.

Concern to carcass crude protein, the level of $1.01 \%$ of true digestible lysine obtained is next at praised by NRC (1998) and Rostagno et al. (2005) for maximum animal performance. Moreover, the higher carcass protein percentage was $18.5 \%$, greater that one obtained by Trindade Neto et al. (2004), $16.5 \%$ with $1.25 \%$ of true digestible lysine in 19\% CP diet.

Moretto et al. (2000) verified increasing linear effect in piglets feed with total lysine changing of 0.85 at $1.25 \%$ in $18 \%$ CP diets. Moreover, the authors recommended $1.15 \%$ of this amino acid in the diet. Similar results were related by Fontes et al. (1997), who also observed linear effect of lysine levels on protein deposition tax in the female pig in nursery phase. By other hand, Moreira et al. (2005) did not have observed effect of lysine levels on protein percentage in female from 6 to $16 \mathrm{~kg}$ of weight. When associated at efficiency of lysine utilization, there was no correlation of this variable with increase of protein synthesis in the animals. According Williams et al. (1997), the higher carcass protein percentage indicate the increase of efficiency of lysine utilization to protein synthesis only when also the others amino acids increase. Moreover, in the present work, the increase of efficiency of lysine utilization until the level of this amino acid that raised higher carcass protein percentage $(1.01 \%)$ could not have been confirmed numerically, since other amino acid can have limited its use with efficiency.

Some works in the literature point the tryptophan how the fourth amino acid more limiting in corn soybean meal diet (LE BELLEGO et al., 2001). By fact, the observation of the amino acids ratio in the experimental diets shows that the tryptophan was between the main amino acids which can have limited the lysine utilization, yonder valine and isoleucin (Table 1).

Regard to carcass fat percentage, there was not difference $(\mathrm{P}>0.05)$ when $18 \% \mathrm{CP}$ diets were used; however, the results showed quadratic effect $(\mathrm{P}<0.01)$ of the lysine levels only when $16 \% \mathrm{CP}$ diets were used, being $0.99 \%$ the true digestible lysine level that propitiate the higher carcass lipid (figure 3).

These results contrast with the find in literature. Moreira et al. (2005) observed a linear decrease in the carcass fat percentage in female from 6 to $16 \mathrm{~kg}$, using crescent levels of lysine in the diets. By other hand, Fontes et al. (2005) observed quadratic effect on fat deposition in the carcass of female pigs in the nursery phase, with the lesser value obtained with $1.25 \%$ of total lysine. These works, the authors utilized higher $\mathrm{CP}$ diets, corresponding at 21 and $19 \%$, respectively. 
Table 3 - Slaughter weight and carcass chemistry composition of piglets at $20 \mathrm{~kg}$ receiving diets with different levels of crude protein and digestible lysine.

\begin{tabular}{|c|c|c|c|c|c|}
\hline \multicolumn{6}{|c|}{ Slayghter Weight $(\mathrm{kg})$} \\
\hline \multirow{2}{*}{ Crude protein $(\%)$} & \multicolumn{4}{|c|}{ Lysine level (\%) } & \multirow{2}{*}{ Average } \\
\hline & 0.7 & 0.9 & 1.1 & 1.3 & \\
\hline 16 & 21.2 & 21.7 & 22.2 & 21.3 & 21.6 \\
\hline 18 & 21.2 & 23.8 & 24.3 & 23.1 & 23.1 \\
\hline Average & 21.2 & 22.8 & 23.3 & 22.2 & \\
\hline $\mathrm{CV}(\%)$ & 7.57 & & & & \\
\hline \multicolumn{6}{|c|}{ Carcass Water (\%) } \\
\hline \multirow{2}{*}{ Crude protein $(\%)$} & \multicolumn{4}{|c|}{ Lysine level $(\%)$} & \multirow{2}{*}{ Average } \\
\hline & 0.7 & 0.9 & 1.1 & 1.3 & \\
\hline 16 & 58.6 & 58.6 & 59.5 & 58.0 & 59.9 \\
\hline 18 & 59.8 & 60.4 & 59.6 & 60.0 & 58.7 \\
\hline Average & 59.2 & 59.5 & 59.6 & 59.0 & \\
\hline $\mathrm{CV}(\%)$ & 5.50 & & & & \\
\hline \multicolumn{6}{|c|}{ Carcass Protein (\%) } \\
\hline \multirow{2}{*}{ Crude protein $(\%)$} & \multicolumn{4}{|c|}{ Lysine level $(\%)$} & \multirow{2}{*}{ Average $^{1}$} \\
\hline & 0.7 & 0.9 & 1.1 & 1.3 & \\
\hline 16 & 15.7 & 16.0 & 16.7 & 16.2 & $16.1 \mathrm{~A}$ \\
\hline $18^{2}$ & 11.2 & 18.1 & 17.4 & 12.7 & $14.9 \mathrm{~B}$ \\
\hline Average & 13.5 & 17.1 & 17.2 & 14.4 & \\
\hline $\mathrm{CV}(\%)$ & 7.35 & & & & \\
\hline \multicolumn{6}{|c|}{ Carcass Fat (\%) } \\
\hline \multirow{2}{*}{ Crude protein $(\%)$} & \multicolumn{4}{|c|}{ Lysine level (\%) } & \multirow{2}{*}{ Average $^{1}$} \\
\hline & 0.7 & 0.9 & 1.1 & 1.3 & \\
\hline $16^{2}$ & 21.1 & 28.4 & 25.9 & 21.2 & $24.2 \mathrm{~A}$ \\
\hline 18 & 19.7 & 20.2 & 22.0 & 20.8 & $20.7 \mathrm{~B}$ \\
\hline Average & 20.4 & 24.3 & 24.0 & 21.0 & \\
\hline $\mathrm{CV}(\%)$ & 10.31 & & & & \\
\hline \multicolumn{6}{|c|}{ Protein Deposition Tax (g/day) } \\
\hline \multirow{2}{*}{ Crude protein $(\%)$} & \multicolumn{4}{|c|}{ Lysine level (\%) } & \multirow{2}{*}{ Average } \\
\hline & 0.7 & 0.9 & 1.1 & 1.3 & \\
\hline 16 & 70.7 & 74.6 & 80.9 & 73.7 & 75.0 \\
\hline $18^{2}$ & 42.9 & 99.1 & 96.3 & 59.1 & 74.4 \\
\hline Average & 56.8 & 86.9 & 88.6 & 66.4 & \\
\hline $\mathrm{CV}(\%)$ & 12.99 & & & & \\
\hline \multicolumn{6}{|c|}{ Fat Deposition Tax (g/day) } \\
\hline \multirow{2}{*}{ Crude protein $(\%)$} & \multicolumn{4}{|c|}{ Lysine level (\%) } & \multirow{2}{*}{ Average $^{1}$} \\
\hline & 0.7 & 0.9 & 1.1 & 1.3 & \\
\hline $16^{2}$ & 34.9 & 84.3 & 71.4 & 36.8 & $56.9 \mathrm{~A}$ \\
\hline $18^{2}$ & 26.9 & 45.4 & 60.8 & 44.4 & $44.3 \mathrm{~B}$ \\
\hline Average & 30.9 & 64.9 & 66.1 & 40.6 & \\
\hline $\mathrm{CV}(\%)$ & 34.31 & & & & \\
\hline
\end{tabular}

${ }^{1}$ Averages followed by different capital letters differ bay $\mathrm{F}$ test $(\mathrm{P}<0.05)$

${ }^{2}$ Significant quadratic effect $(\mathrm{P}<0.05)$

According to Trindade Neto et al. (2004), a greater variation is between the animals concern at fat tissue quantity in the carcass. The increase of fat percentage observed until $0.99 \%$ of digestible lysine can be explained for use of this amino acid for energy synthesis. Above this, the excess of methionine and threonine can have been directed to synthesis of other amino acids that were limiting, since the quantity of no essential amino acids supplied by diet was lesser in diets with this level of protein applied. In this case, the exceeding lysine can have been directed again for the protein synthesis, therefore the differenced behavior of quadratic curve observed. 


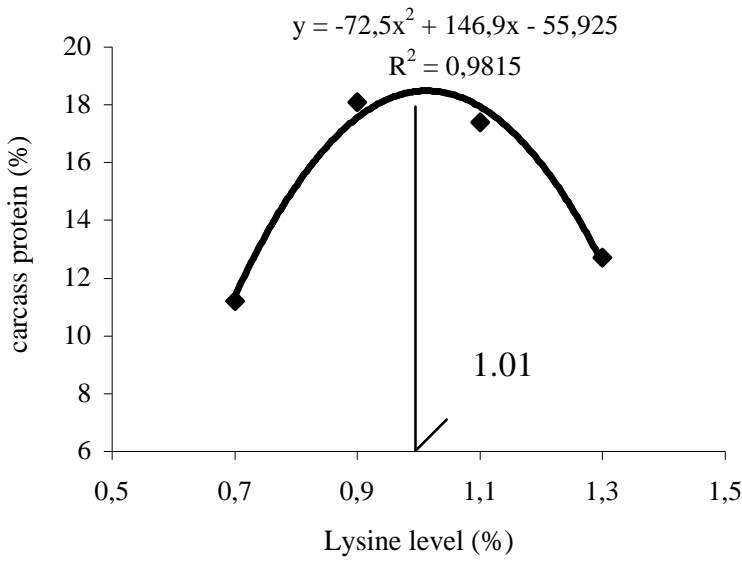

Figure 2 - Carcass protein (\%) of piglets at $20 \mathrm{~kg}$ receiving diets with $18 \%$ of crude protein and increasing levels of true digestible lysine.

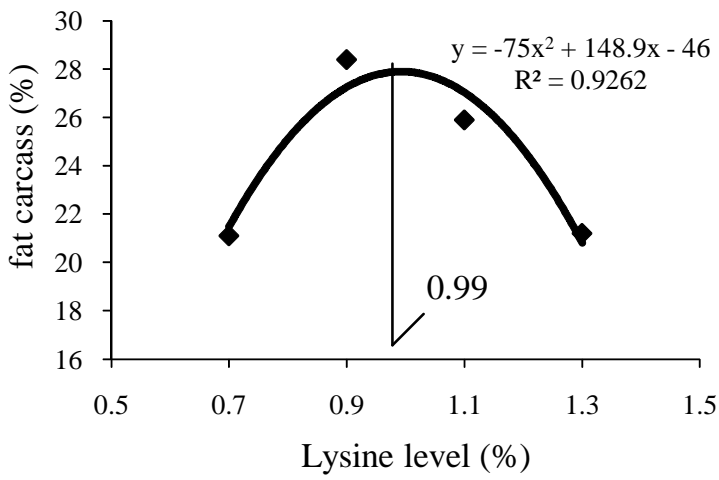

Figure 3 - Carcass fat (\%) of piglets at $20 \mathrm{~kg}$ receiving diets with 16 and $18 \%$ of crude protein and increasing true digestible lysine.

According Jongbloed \& Lenis (1998), the utilization of reduced CP diets supplied with amino acids promote higher accumulation of fat in carcass due to lesser energy expense for metabolization of these amino acids (lesser caloric increment) and, consequently, higher release of energy to be deposit in corporal tissue. In the present work, the animal group that receive $16 \% \mathrm{CP}$ diet showed higher carcass fat percentage $(\mathrm{P}<0.05)$, confirming the hypothesis these authors. Agreement Trindade Neto et al. (2004), the fat : protein ratio is as indicative of efficiency of protein synthesis, in response at amino acid balance in the diet.

With regard to protein deposition tax, there was interaction $(\mathrm{P}<0.05)$ between the digestible lysine and $\mathrm{CP}$ in the diet. A quadratic effect of the lysine levels in $18 \% \mathrm{CP}$ diet was observed $(\mathrm{P}<0.01)$, whose increase was observed until $1.02 \%$ of this amino acid (figure 4). There was no difference $(\mathrm{P}>0.05)$ when $16 \% \mathrm{CP}$ was utilized.

Similarly these results, Moretto et al. (2000) observed that the lysine levels changing of 0.85 at $1.05 \%$ influenced in quadratic form the protein deposition tax in piglets that increase until $1.04 \%$ of this amino acid in $18 \%$ CP diet. Agreement these authors, there was best amino acid balance with the addition of lysine. Already Campbell et al. (1988), showed that, maintaining the amino acid ratio between the essential ones, and these with the $\mathrm{CP}$ level in the diet, is possible to obtain positive response of carcass composition of pigs, even with their levels higher that the recommended by nutrition requirements tables. In the present work, the no addition of others amino acids did not permit the observation of these results in $16 \% \mathrm{CP}$ diets.

The variation of estimated lysine intake of 4.96 until $7.4 \mathrm{~g} /$ day ( $1.02 \%$ of digestible lysine) was fundamental in the daily protein deposition, according also Trindade Neto et al. (2000) verified when worked with swine in nursery phase. Basing this values, the estimative of consume of these amino acids overtake the recommendation of $6.75 \mathrm{~g}$ /day praised by NRC (1998).

With regard to fat deposition tax, there was quadratic effect when $18 \% \mathrm{CP}(\mathrm{P}<0.05)$ and $16 \% \mathrm{CP}$ $(\mathrm{P}<0.01)$ diets were used, whose lysine levels that resulted in higher increase were 1.08 and $1.00 \%$, respectively (figure 5).

The higher accumulation of lipid observed in the animal group that receive $16 \% \mathrm{CP}$ diets is accordance to Oliveira (2004), whose work it was verified that this deposition tax is higher in animals that receive diets

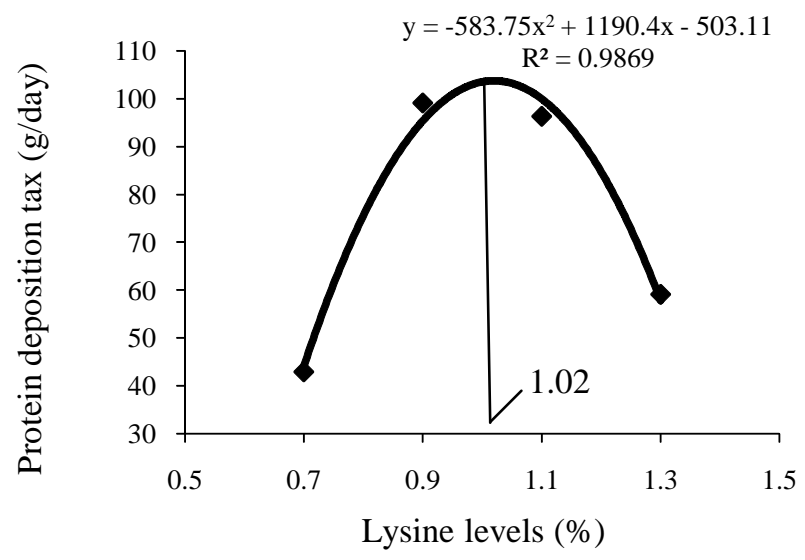

Figure 4 - Protein deposition tax (g/day) of piglets at 20 $\mathrm{kg}$ receiving diets with 16 and $18 \%$ of crude protein and increasing true digestible lysine. 


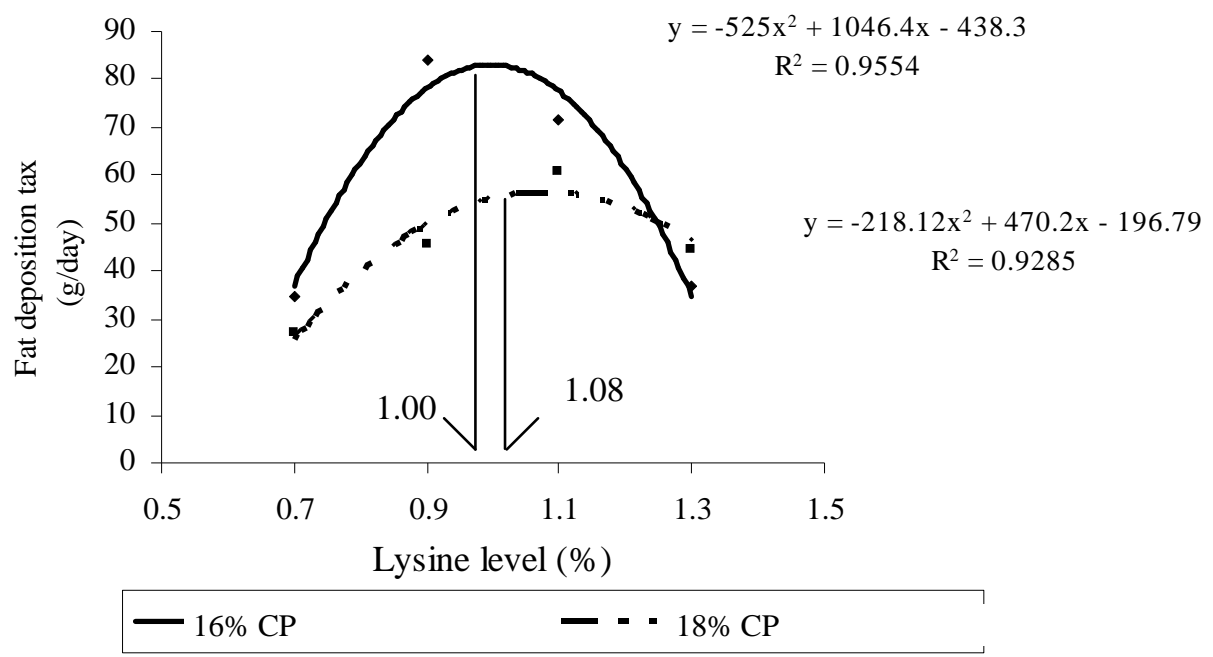

Figure 5 - Fat deposition tax (g/day) of piglets at $20 \mathrm{~kg}$ receiving diets with 16 and $18 \%$ of crude protein and increasing true digestible lysine.

with reduced crude protein levels. Moreira et al. (2005) observed a linear decrease of fat deposition tax in pigs in the nursery phase receiving increasing lysine levels in 21.6 $\mathrm{CP}$ diets. Similar results with growing animals were obtained by Le Bellego et al. (2001).

Agreement Van Milgen et al. (2001), the replace of soybean meal by starch in $16 \% \mathrm{CP}$ diets compared that with higher protein level, can interfere in these results, once that the digestible energy of this second ingredient is utilized with higher efficiency compare to protein food.

\section{CONCLUSION}

The level of $1.02 \%$ of true digestible lysine is the ideal and the level of $18 \% \mathrm{CP}$ in de diet must be maintained to the best carcass composition in the pigs in the nursery phase.

\section{ACKNOWLEDGE}

The authors gratefully acknowledge the FAPEMIG (Research Support Foundation of Minas Gerais ) for their financial support in this project.

\section{LITERATURE CITED}

AROUCA, C.L.C.; FONTES, D.O.; BAIÃO, N.C.; SILVA, M.A.; SILVA, F.C.O. Níveis de lisina para suínos machos castrados selecionados geneticamente para deposição de carne magra na carcaça, dos 95 aos 122 kg. Ciência e Agrotecnologia, Lavras, v.31, n.2, p. 531539, 2007.
BAKER, D.H. Advances in amino acid nutrition and metabolism of swine and poultry. In: KORNEGAY, E.T. (Ed.). Nutrient management of food animals to enhance and protect the environment. Boca Raton: CRC, 1996. p.41-53.

CAMPBELL, R.G., TAVERNER, M.R., CURIC, D.M. The effects of sex and live weight on the growing pig's response to dietary protein. Animal Production, 46, p. 123-130, 1988.

FERREIRA, D.F. Análises estatísticas por meio do Sisvar para Windows versão 4. 0. In: REUNIÃO ANUAL DA REGIÃO BRASILEIRA DA SOCIEDADE

INTERNACIONAL DE BIOMETRIA, 45., 2000, São Carlos. Anais... São Carlos, SP: UFSCar, 2000. p.255-258.

FIGUEROA, J.L.; LEWIS, A.J.; MILLER, P.S.; FISCHER, R.L.; GÓMEZ, R.S.; DIEDRICHSEN, R.M. Nitrogen metabolism and growth performance of gilts fed standard corn-soybean meal diets or low-crude protein, amino acid-supplemented diets. Journal of Animal Science, Champaign, v.80, n.11, p.2911-2919, 2002.

FONTES, D.O.; DONZELE, J.L.; CONHALATO, G.S. Níveis de lisina para leitoas com alto potencial genético para deposição de carne magra, dos 15 aos $30 \mathrm{~kg}$. In: REUNIÃO ANUAL DA SOCIEDADE DE ZOOTECNIA, 34., 1997, Juiz de Fora. Anais... Juiz de Fora, MG: SBZ, 1997. p.78-80. 
FONTES, D.O.; DONZELE, J.L.; OLIVEIRA, R.F.M.; SILVA, F.C.O.; LOPES, D.C. Níveis de lisina para leitoas selecionadas geneticamente para deposição de carne magra na carcaça, dos 15 aos $30 \mathrm{~kg}$. Revista Brasileira de Zootecnia, Viçosa, v.34, n.1, p.90-97, 2005.

FULLER, M.; WANG, T.C. Digestible ideal protein - a measure of dietary protein value. Pig News Information, v.11, n.3, p.353-357, 1990.

JONGBLOED, A.W.; LENIS, N.P. Environmental concerns about animal manure. Journal of Animal Science, Champaign, v.76, p.2641-2648, 1998.

KERR, B.J.; ZIEMER, C.J.; TRABUE, S.L.; CROUSE, J.D.; PARKIN, T.B. Influences of dietary protein level, amino acid supplementation and environmental temperature on performance, body composition, organ weights and total heat production of growing pigs. Journal of Animal Science, Champaign, v.81, n.8, p. 1998-2007, 2003.

KYRIAZAKIS, I.; DOTAS, D.; EMMANS, G.C. The effects of breed on the relationship between feed composition and the efficiency of protein utilization in pigs. British Journal of Nutrition, v.71, n.5, p.849-859, 1994.

LE BELLEGO, L.; VAN MILGEN, J.; DUBOIS, S.; NOBLET, J. Energy utilization of low-protein diets in growing pigs. Journal of Animal Science, Champaign v. 79, n. 5, p. 1259-1271, 2001.

LE BELLEGO, L.; VAN MILGEN J.; NOBLET, J. Effect of high temperature and low-protein diets on performance of growing pigs. Journal of Animal Science, Champaign, v.80, n.3, p.691-701, 2002.

MOREIRA, H.F.V.; MOREIRA, H.F.V.; FONTES, D.O.; SILVA, F.C.O.; SILVA, M.A.; FONTES, F.A.P.V.; GOMES, F.F.E.; ROSSONI, M.C. Níveis de lisina para leitoas dos 6 aos $16 \mathrm{~kg}$ com alto potencial para deposição de carne magra na carcaça. Revista Brasileira de Zootecnia, Viçosa, v.34, n.4, p.1210-1216, 2005.

MORETTO, V.; DONZELE, J.L.; OLIVEIRA, R.F.M.; FONTES, D.O. Níveis dietéticos de lisina para suínos da raça Landrace dos 15 aos $30 \mathrm{~kg}$. Revista Brasileira de Zootecnia, Viçosa, v.29, n.3, p.803-809, 2000.

\section{NATIONAL RESEACH COUNCIL. Nutrient} durante o crescimento.. 10.ed. Washington: National Academy of Sciences, 1998.

OLIVEIRA, V.; FIALHO, E.T.; LIMA, J.A.F.; BERTECHINI, A.G.; FREITAS, R.T.F. Teor de proteína no metabolismo do nitrogênio e da energia em suínos durante o crescimento. Ciência e Agrotecnologia, Lavras, v.29, n.4, p. 866-874, 2005.

OLIVEIRA, V.; FIALHO, E.T.; LIMA, J.A.F.; FREITAS, R.T.F.; BERTECHINI, A.G.; ARAUJO, J.S. Características de carcaça e peso de vísceras em suínos alimentados com rações contendo baixos teores de proteína bruta. Ciência Rural, Santa Maria, v. 36, n. 06, p. 1890-1895, 2006.

ROSTAGNO, H.S.; ALBINO, L.F.T.; DONZELE, J.L.; GOMES, P.C.; FERREIRA, A.S.; OLIVEIRA, R.F.; LOPES, D.C. Tabelas brasileiras para aves e suínos: composição de alimentos e exigências nutricionais. Viçosa: UFV. Departamento de Zootecnia, 2000. 141p.

ROSTAGNO, H. S.; ALBINO, L. F. T.; DONZELE, J. L.; GOMES, P. C.; OLIVEIRA, R. F ; LOPES, D. C ; FERREIRA, A. S. ; BARRETO, S.L.T. Tabelas brasileiras para aves e suínos: composição de alimentos e exigências nutricionais. 2.ed. Viçosa: UFV, 2005. 186p.

SILVA, D.J.; QUEIROZ, A.C. Análises de alimentos: métodos químicos e biológicos. Viçosa: UFV, 2002. 235p.

SUSENBETH, A. Factors affecting lysine utilization in growing pigs: an analysis of literature data. Livestock Production. Science, v.43, p.193, 1995.

TRINDADE NETO, M.A.; KRONKA, R.N.; BARBOSA, H.P. PETELINCAR, I.M.; SCHAMMASS, E.A. Níveis de lisina para suínos na fase inicial-1 do crescimento, desempenho e retenção de nitrogênio. Boletim da Indústria Animal, Nova Odessa, v.57, n.1, p.65-74, 2000.

TRINDADE NETO, M.A.; PETELINCAR, I.M.; BERTO, D.A.; SCHAMMASS, E.A.; BISINOTO, K.S.; CALDARA, F.R. Níveis de lisina para leitões na fase inicial-1 do crescimento pós-desmame: composição corporal aos 11,9 e 19,0 kg. Revista Brasileira de Zootecnia, Viçosa, v.33, n.6, p.1777-1789, 2004. (Supl., 1). 
TUITOEK, J.K.; YOUNG, L.G.; LANGE, C.F.; KERR, B.J. Body composition and protein and fat accretion in various body components in growing gilts fed diets with different protein levels but estimated to contain similar levels of ideal protein. Journal of Animal Science, Champaign v.75, n.6, p.1584-1590. 1997.

VAN MILGEN, J.; NOBLET, J.; DUBOIS, S. Energetic efficiency of starch, protein and lipid utilization in growing pigs. Journal of Nutrition, Bethesda, v.131, n.4, p.1309-1318, Apr. 2001.

VERSTEGEN, M.W.A.; DE GREEF, K.H. Influence of environmental temperature on protein and energy metabolism in pig production. In: SIMPÓSIO INTERNACIONAL DE NÃO RUMINANTES, 1992, Lavras. Anais... Lavras: SBZ, 1992. p.1-42.

WILLIAMS, N.H.; STAHLY, T.S.; ZIMMERMAN, D.R. Effect of chronic immune system activation on the rate, efficiency, and composition of growth and lysine needs of pigs fed from 6 to $27 \mathrm{~kg}$. Journal of Animal Science, Champaign v.75, n.9, p.2463-2471, 1997.
ZALOGA, G.P. Physiologic effects of peptide-based enteral formulas. Nutrition Clinical Practical, New York, v.5, n.6, p.231-237, 1990.

ZANGERONIMO, M.G.; FIALHO, E.T.; MURGAS, L.D.S.; FREITAS, R.T.F.; RODRIGUES, P.B. Desempenho e excreção de nitrogênio de leitões dos 9 aos $25 \mathrm{~kg}$ alimentados com dietas com diferentes níveis de lisina digestível e proteína bruta. Revista Brasileira de Zootecnia, Viçosa, v.36, n.5, p.1382-1387. 2007a.

ZANGERONIMO, M.G.; FIALHO, E.T.; MURGAS, L.D.S.; LIMA, J.A.F.; ROCHA, E.V.H.; ALVARENGA, R.R. Efeito de níveis de lisina digestível verdadeira e proteína bruta na dieta sobre parâmetros morfofisiológicos e utilização do nitrogênio em suínos na fase inicial. Ciência e Agrotecnologia, Lavras, v.31, n.2, p.506-513. 2007b.

ZANGERONIMO, M.G.; FIALHO, E.T.; LIMA, J.A.F.; GIRÃO, L.V.C.; AMARAL, N.O.; SILVEIRA, H.

Desempenho e características de carcaça de suínos dos 20 aos $50 \mathrm{~kg}$ recebendo rações com reduzido teor de proteína bruta e diferentes níveis de lisina digestível verdadeira. Ciência Rural [on line], Santa Maria, 2009. 